\title{
An intervention programme for improving the nutritional status of children aged 2-5 years in Alexandria
}

E.H. Ghoneim 1, M.H.A. Hassan ${ }^{2}$ and E.K. Amine ${ }^{3}$

$$
\begin{aligned}
& \text { برنامج تدخُّلي لتحسين الحالة التغذوية للأطفال البالغين من العمر 2-5 أعو ام بالإسكندرية }
\end{aligned}
$$

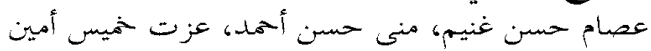

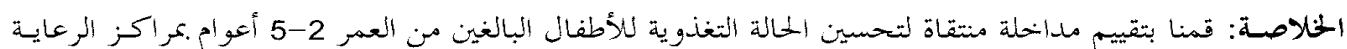

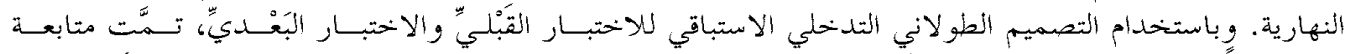

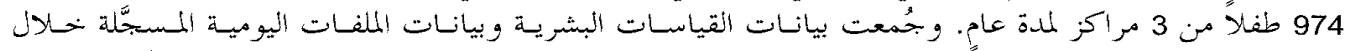

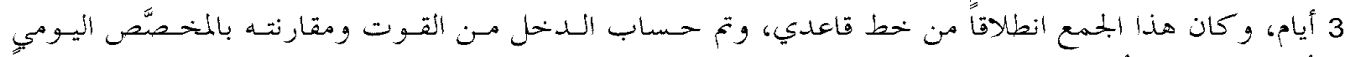

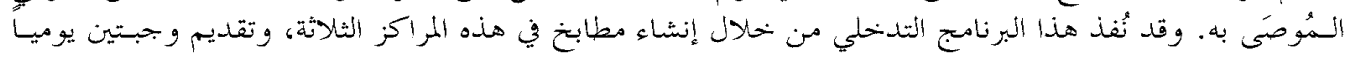

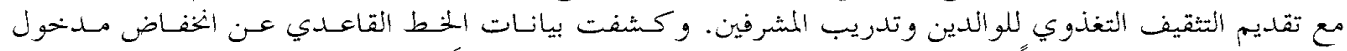

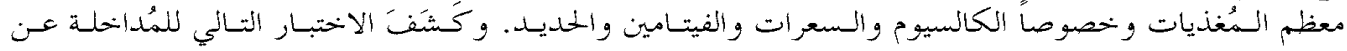

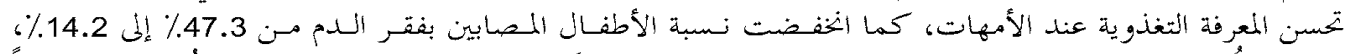

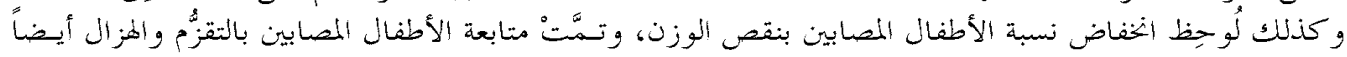
أثناء هذا البر نامج. وقد بل بلغت تكلفة البرنامج لكل طفل في العام 20.5 دولار.

ABSTRACT We assessed the effect of a selected intervention on the nutritional status of 2-5-year-old children in day care centres. Using a longitudinal prospective pretest/post-test intervention design, 974 children from 3 day care centres in Alexandria were followed for 1 year. Anthropometric measurements and 3-day 24-hour recall data were gathered at base line and dietary intake was calculated and compared with recommended daily allowances. An intervention programme was implemented through the establishment of kitchens in the 3 centres, provision of 2 meals/day, nutrition education for parents and training of supervisors. Baseline data revealed deficient intake of most nutrients especially calcium, calories, vitamin C and iron. Post-intervention test revealed improvement in mothers' nutrition knowledge and the percentage of anaemic children decreased from $47.3 \%$ to $14.2 \%$. A decrease in the percentage of underweight, stunted and wasted was also observed. The cost of the programme per child per year was US\$20.5.

Programme d'intervention pour améliorer l'état nutritionnel des enfants âgés de 2 à 5 ans à Alexandrie RÉSUMÉ Nous avons évalué l'effet d'une intervention sélectionnée sur l'état nutritionnel des enfants âgés de 2 à 5 ans dans des garderies. En utilisant un modèle d'intervention prospectif longitudinal pré-test/post-test, 974 enfants de trois garderies à Alexandrie ont été suivis pendant un an. Des mesures anthropométriques ont été prises et des données du rappel des 24 heures sur trois jours ont été recueillies au début de l'intervention ; l'apport alimentaire a été calculé et comparé avec les apports journaliers recommandés. Un programme d'intervention a été exécuté avec la mise en place de cuisines dans les trois garderies, la fourniture de deux repas par jour, l'éducation nutritionnelle pour les parents et la formation du personnel d'encadrement. Les données initiales ont révélé un apport insuffisant pour les plupart des nutriments, notamment le calcium, les calories, les vitamines et le fer. Le test post-intervention a montré une amélioration des connaissances des mères en matière de nutrition, et le pourcentage d'enfants anémiques a chuté de $47,3 \%$ à $14,2 \%$. Une diminution de la proportion d'enfants présentant une insuffisance pondérale, ayant un retard de croissance et émaciés a également été observée. Le coût du programme par enfant et par année s'élevait à USD 20,5.

${ }^{1}$ Central Laboratory for Food and Feed, Agricultural Research Centre, Ministry of Agriculture, Alexandria, Egypt.

${ }^{2}$ Department of Biostatistics; ${ }^{3}$ Department of Nutrition, High Institute of Public Health, University of Alexandria, Alexandria, Egypt.

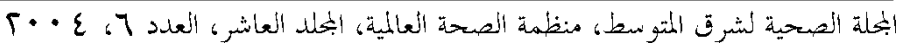




\section{Introduction}

In Egypt, the health status of the population has improved rapidly due to improvements in health services and in the economic achievement thus improving the quality of life both in urban and rural areas [1]. However, it has been reported that about $50 \%$ of preschool children in urban areas of Alexandria were anaemic, $5 \%$ were stunted, $2.4 \%$ were wasted and $15 \%$ were obese $[2,3]$. Studies in rural and squatter areas reported up to $20 \%$ stunting, $11 \%$ wasting and $4 \%$ obese $[4,5]$.

The changing eating habits due to introduction of fast foods and snacks and the affluent lifestyle have provided a wide variety of foods for children and mothers. Moreover, nowadays it is more difficult to remain aware of the nutritional values of food because of prepackaging, vending machines and fast-food restaurants. Increasingly frequently you find, "formulated", non-nutritious food replacing wholesome foods in the diet, especially children's foods and snacks. Parents also wrongfully teach their children by using rewards to encourage them to eat. Remarks such as "eat your meat and after that you can have your chocolate" encourage children to want to eat more sweet and sugary foods. Furthermore, the increasing habit of the eating out aggravates the problem of unhealthy eating and unbalanced diets [6].

Health-care professionals believe that lifelong eating habits and risk factors for chronic disease begin in early childhood [6]. Nutrition interventions targeted at children include diet therapy, counselling or use of specialized nutrition supplements, and nutrition monitoring and evaluation [68]. The dietary guidelines, which recommend food choices to promote health and decrease the risk of chronic disease for people 2 years of age and older, include 8 items that apply to children as well as adults
[9]. Several recent large-scale studies have noted declines in fat intake among preschool and primary-school children and adolescents, but currently reported fat intake $-33 \%$ to $35 \%$ of total daily calories-still exceeds, by 3 to 4 percentage points, the recommended dietary allowances (RDAs) $[10,11]$. The average diet of children and adolescents includes too much fat, saturated fat, and sodium and too few servings of fruits, vegetables and calcium $[11,12]$. National surveys indicate that overweight among children is a growing problem and that children from lower income families are at greater risk of obesity, increased serum lipid levels and food intakes that fail to meet the RDAs than are children of higher socioeconomic status $[10,12]$.

The principal objectives of the present study were: to assess the feasibility of providing nutrition intervention to $2-5$-yearold children in day care centre settings; to help mothers develop important concepts, attitudes and behaviour toward food and to be able to make wise choices about their children's food; and to evaluate the effect of a selected intervention on the nutritional status of children.

\section{Methods}

A longitudinal prospective pretest/post-test intervention design was used where the study population was composed of all children aged 2-5 years, from 3 day care centres run by Al Moasat Organization located in 3 areas of Alexandria (Anfushy, Smouha and Boulkly) representing different socioeconomic levels.

\section{Sampling}

All children enrolled in the 3 day care centres and aged 2-5 years at the time of the study (October 2000 to September 2001)

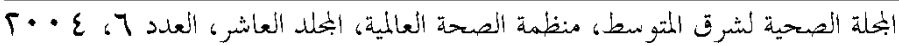


were included in the study (974 children). All mothers were invited to participate and their consent was obtained. Of these, 935 mothers submitted a complete questionnaire with 24-hour recall over 3 days. Stool samples were taken for all children. After 1 year, 563 children $(60.2 \%)$ remained for final nutritional assessment. The $40 \%$ not included were because the child had gone to school, or was absent because of mother's vacation, or the child's data were incomplete and he/she was therefore excluded from the final analysis. A subsample of children was systematically selected in proportion to the number of children in each centre for blood and stool sampling; special consent was obtained from the parents. The estimated minimum required subsample using Epi-Info was 280 children. These were chosen in a systematic manner from the 3 day care centres. Of these, 214 (76.4\%) consented to blood sampling and had a negative stool analysis. Any children with positive stool sample were referred to a physician and were excluded from the analysis but not from the intervention. After 1 year 66 children were lost to follow up (30.8\% attrition) leaving 148 children $(69.2 \%)$ for final blood sampling. No significant difference was found between respondents and non-respondents in sociodemographic characteristics whether in blood sample or for anthropometry.

\section{Data collection}

Mothers were interviewed by trained supervisors in the nursery about sociodemographic characteristics of mother and child. After the interview they were asked to record at home the 24-hour recall of all food and drinks intake of their children over 3 days including a week-end. Food quantities were expressed by the mothers in common household measures (spoons, cups, etc.) and converted to weights in grams. The recall responses were transformed to the average nutrient intake per day using food composition tables of the Egyptian Nutrition Institute using EXCEL [13]. Then these nutrients were compared to the RDAs for age and sex [13].

\section{Nutritional assessment}

Two parameters were used to evaluate the nutritional status of the children; anthropometric measurements (weight and height) and biochemical analysis (haemoglobin concentration, blood lead and cadmium). For measurement of height, the child stood erect, without shoes with weight equally distributed on both feet and heels together and touching the vertical board and looking straight ahead. Height was recorded to the nearest $0.1 \mathrm{~cm}$. Body weight was measured on a levelled platform scale with movable weights. The child, in minimum clothing and without shoes, stood with weight evenly distributed on both feet. Weight was recorded to the nearest $100 \mathrm{~g}$. Measurements of weight and height were evaluated by comparison with tables derived from a reference population [14]. The same instruments were used before and after the intervention and reliability was checked repeatedly; those taking the measurements were trained and remained the same. Stool analysis was performed to exclude parasitic infection.

Because of its low cost, easy and rapid application, the test most commonly used to screen for anemia is haemoglobin level. This measure reflects the amount of functional iron in the body. The concentration of haemoglobin in circulating red blood cells is the most direct and sensitive measure (colorimetric method) [15]. The WHO criterion for iron deficiency anaemia (haemoglobin level $<11 \mathrm{~g} / \mathrm{dL}$ ) was used to diagnose anaemic children [16]. All laboratory investigations were carried out by one 
of the staff members of the Faculty of Medicine, University of Alexandria.

\section{Intervention programme}

The intervention programme included the following activities.

- Updating of the 3 kitchens, dining rooms and stocks where all old utensils were exchanged by new stainless steel ones. Also, kitchens were equipped with the needed electric machines. The floor was covered by tiles and ceramic, sewage disposal (bathrooms) was renovated and windows were covered by nets.

- Training of supervisors (the nursery care givers) by university staff members on the nutritional requirements of children and handling of children's food. The training was implemented through 60 theoretical and 40 practical teaching hours over 25 days for 100 supervisors and 15 graduate assistants.

- Health education of parents consisting of 12 sessions including lectures given by university staff about healthy child feeding practices and feeding schedules of children.

- Nutritional programme which included 2 meals per day (breakfast and lunch) and a fruit snack in between. Meals were selected carefully to be rich in proteins, iron and vitamins and free of additives. The programme was devised by 2 of the authors together with university consultants. Purchases and preparation of food was done in teams and all members were trained.

The cost of the intervention amounted to US\$ 20.5 per child per year. This was calculated from the total cost of the programme for the year which amounted to LE 206 160. With 1500 children enrolled, the cost per child was LE 137.44. At the time of the study the rate of exchange was US\$ $1=$ LE 6.8 .

\section{Programme evaluation}

The programme was evaluated by comparing the nutritional status of the children before and after the intervention, mother's nutritional awareness by a pre- and posttest and programme costs. Mother's knowledge was assessed by a 20 -item Likert scale questionnaire where the answers are scored as 2 for agree, 1 for undecided and zero for disagree. Percentage scores were calculated.

\section{Data analysis}

Data were analysed using Epi-Info 2000, Microsoft Excel XP and SPSS, version 10.0. A $P$-value of 0.05 was used for statistical significance and all tests were twosided. The arithmetic mean, standard deviation and percentage were used as summary statistics. The shape of the distribution of quantitative variables was explored using the Kolmogorov-Smirnov one-sample test. Comparison among proportions was performed using Cramer's V and paired comparison before and after the programme was performed using $\mathrm{McNe}-$ mar test where the binomial distribution with exact $P$-values was applied. Univariate analyses of data on nutritional indicator Z-score and haemoglobin level were performed using the paired $t$-test for normally distributed data and the Wilcoxon signed rank test for skewed data. General linear model repeated measures ANOVA was used to examine simultaneously the within subject (intervention) effect as well as the between subjects effect of sociodemographic factors on the response to the intervention programme. For multiple comparison among means Tukey HSD test was used $[17,18]$.

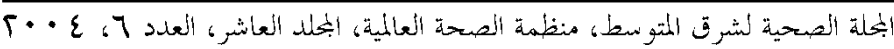




\section{Results}

The present study included 935 children at baseline assessment; 314 each from Anfushy and Smouha day care centres and 307 from Boulkly nursery (Table 1). About $65 \%$ of the children were between 2 and 4 years and the remaining $35 \%$ were $4-<6$ years. Children were fairly equally distributed by sex ( $48.4 \%$ boys and $51.6 \%$ girls). More than $50 \%$ of mothers were university educated, $38.1 \%$ had had vocational education and only $9.7 \%$ were illiterate or could just read and write. As expected, mothers were mostly working $(67.7 \%)$. The birth order of child was first or second for $47.4 \%$ of the study children and $52.6 \%$ were the third or higher birth order. The 3 day care centres showed significant difference in all sociodemographic characteristics. Smouha and Boulkly had higher percentages of university educated mothers than Anfushy and also higher proportions of lower birth orders.

Table 2 shows the percentage of children consuming a daily average of nutrients $\geq 100 \%$ the RDAs. The most deficient nutrient was calcium (only $22.1 \%$ consumed $\geq 100 \%$ the RDAs), followed by calories (26.4\%) and vitamin C (39.1\%). The least deficient nutrient was proteins $(98 \%$ consumed $\geq 100 \%$ the RDAs) followed by vita$\min \mathrm{B}_{2}(71.0 \%)$ and vitamin $\mathrm{A}(60.3 \%)$. Comparison of the 3 day care centres revealed significant difference between them in the percentage of children consuming $\geq 100 \%$ the RDAs of vitamin $\mathrm{B}_{1}$, vitamin $\mathrm{B}_{2}$ and niacin with lower percentages in Anfushy than Smouha and Boulkly.

The mean (and standard deviation) score of mother's knowledge, was $78.5 \%$ (SD 10.8\%) before the intervention which

\begin{tabular}{|c|c|c|c|c|c|c|c|c|c|}
\hline \multirow[t]{2}{*}{ Characteristic } & \multicolumn{2}{|c|}{$\begin{array}{c}\text { Anfushy } \\
(n=314)\end{array}$} & \multicolumn{2}{|c|}{$\begin{array}{l}\text { Smouha } \\
(n=314)\end{array}$} & \multicolumn{2}{|c|}{$\begin{array}{c}\text { Boulkly } \\
(n=307)\end{array}$} & \multicolumn{2}{|c|}{$\begin{array}{c}\text { Total } \\
(n=935)\end{array}$} & \multirow[t]{2}{*}{$\begin{array}{c}\text { Cramer's } \\
V\end{array}$} \\
\hline & No. & $\%$ & No. & $\%$ & No. & $\%$ & No. & $\%$ & \\
\hline Age (months) & & & & & & & & & $0.34^{\star \star \star}$ \\
\hline $24-$ & 133 & 42.4 & 255 & 81.2 & 217 & 70.7 & 605 & 64.7 & \\
\hline $48-$ & 181 & 57.6 & 59 & 18.8 & 90 & 29.3 & 330 & 35.3 & \\
\hline Sex & & & & & & & & & $0.10^{\star \star}$ \\
\hline Male & 136 & 43.3 & 174 & 55.4 & 143 & 46.6 & 453 & 48.4 & \\
\hline Female & 178 & 56.7 & 140 & 44.6 & 164 & 53.4 & 482 & 51.6 & \\
\hline Mother's education & & & & & & & & & $0.35^{\star \star \star}$ \\
\hline Less than secondary & 79 & 25.2 & 6 & 1.9 & 6 & 2.0 & 91 & 9.7 & \\
\hline Vocational & 160 & 51.0 & 77 & 24.5 & 119 & 38.8 & 356 & 38.1 & \\
\hline University & 75 & 23.9 & 231 & 73.6 & 182 & 59.3 & 488 & 52.2 & \\
\hline Mother's work & & & & & & & & & $0.35^{\star \star \star}$ \\
\hline Working & 143 & 45.5 & 261 & 83.1 & 229 & 74.6 & 633 & 67.7 & \\
\hline Non-working & 171 & 54.5 & 53 & 16.9 & 78 & 25.4 & 302 & 32.3 & \\
\hline Birth order & & & & & & & & & $0.13^{\star \star}$ \\
\hline$<3 r d$ & 133 & 42.4 & 137 & 43.6 & 173 & 56.4 & 443 & 47.4 & \\
\hline $3 r d+$ & 181 & 57.6 & 177 & 56.4 & 134 & 43.6 & 492 & 52.6 & \\
\hline
\end{tabular}

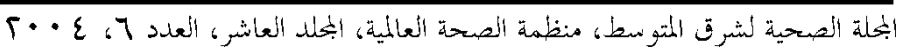


Table 2 Nutrients intake at baseline assessment in relation to recommended daily allowances (RDAs)

\begin{tabular}{|c|c|c|c|c|c|}
\hline Nutrient & $\begin{array}{l}\text { Percent } \\
\text { Anfushy } \\
(n=314)\end{array}$ & $\begin{array}{l}\text { age consu } \\
\text { Smouha } \\
(n=314)\end{array}$ & $\begin{array}{c}\text { Iming } \geq 100 \\
\text { Boulkly } \\
(n=307)\end{array}$ & $\begin{array}{c}\% \text { RDAs } \\
\text { Total } \\
(n=935)\end{array}$ & $\underset{V}{\text { Cramer's }}$ \\
\hline Calories & 25.2 & 30.9 & 23.1 & 26.4 & 0.08 \\
\hline Protein & 98.7 & 98.4 & 96.7 & 98.0 & 0.06 \\
\hline Calcium & 18.2 & 23.2 & 25.1 & 22.1 & 0.07 \\
\hline Iron & 43.6 & 39.2 & 35.2 & 39.4 & 0.07 \\
\hline Vitamin A & 59.6 & 63.7 & 57.7 & 60.3 & 0.05 \\
\hline Vitamin $B_{1}$ & 37.9 & 48.1 & 45.3 & 43.7 & $0.09^{*}$ \\
\hline Vitamin $B_{2}$ & 64.0 & 74.2 & 74.9 & 71.0 & $0.11^{\star *}$ \\
\hline Vitamin C & 40.1 & 37.3 & 40.1 & 39.1 & 0.03 \\
\hline Niacin & 32.2 & 54.1 & 48.2 & 44.8 & $0.19^{\star \star \star}$ \\
\hline
\end{tabular}

${ }^{*} \mathrm{P}<0.05 ;{ }^{* *} \mathrm{P}<0.01 ;{ }^{* *} \mathrm{P}<0.001$

increased significantly 1 year after the intervention to $91.8 \%$ (SD $6.0 \%$ ). This improve- ment was greatest in Anfushy [from $81.5 \%$ (SD $7.5 \%$ ) to $92.0 \%$ (SD $3.4 \%$ )] while in Smouha it increased from $84.2 \%$ (SD 5.6\%) to $91.0 \%$ (SD 3.0\%) and in Boulkly it increased from $76.5 \%$ (SD $5.5 \%$ ) to $85.0 \%$ (SD 2.6\%).

Table 3 shows the categories of the nutritional status $Z$-scores $(<-2,+2$ and +2 $\mathrm{SD})$ before and after the intervention by nursery and sex. The percentage of underweight boys before the intervention was $4.6 \%$ which decreased 1 year after the programme to $1.5 \%$. The comparative percentages among girls were $4.6 \%$ and $0.3 \%$. As regards the percentage of stunted boys and girls they were $5 \%$ and $4.6 \%$ before the intervention compared to $3.5 \%$ and $2.3 \%$ after the intervention respectively. Wasting was present among $1.9 \%$ of boys and $2.3 \%$ of girls before the intervention compared with $0.0 \%$ and $0.3 \%$ respectively after the intervention. These findings were consistent for the 3 day care centres.
Among the whole sample and for both sexes there was a significant improvement in the nutritional status after the intervention in all indices with a few exceptions in the height-for-age Z (HAZ) score among boys in Smouha and Boulkly. Also no significant difference was found in weight-for-height $\mathrm{Z}$ (WHZ) scores among boys and HAZ scores among girls in Smouha. As regards overweight, $4.6 \%$ of boys and $6.9 \%$ of girls were overweight before the intervention; this rose to $8.5 \%$ and $11.5 \%$ respectively after the intervention..

Table 4 illustrates the simultaneous analysis of the within subject intervention effect and the between subjects effect of sociodemographic factors on the mean nutrition indices $Z$ scores. There was a highly significant within subject effect which reflects the success of the programme in improving the nutrition status of a child regardless of which group he/she belonged to. However a significant interaction effect was noticed between intervention on the one hand and each of sex, nursery, moth-

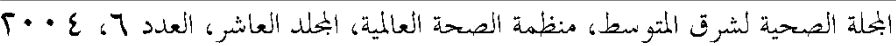




\begin{tabular}{|c|c|c|c|c|c|c|c|c|}
\hline \multirow[t]{2}{*}{ Z score } & \multicolumn{2}{|c|}{ Anfushy } & \multicolumn{2}{|c|}{ Smouha } & \multicolumn{2}{|c|}{ Boulkly } & \multicolumn{2}{|c|}{ Total } \\
\hline & Before & After & Before & After & Before & After & Before & After \\
\hline & \multicolumn{8}{|c|}{ Boys } \\
\hline No. examined & 104 & & 70 & & 85 & & 259 & \\
\hline \multicolumn{9}{|l|}{ Weight-for-age } \\
\hline$<-2$ & 4.8 & 1.9 & 4.3 & 0.0 & 3.5 & 2.4 & 4.2 & 1.5 \\
\hline \pm 2 & 87.5 & 82.7 & 94.3 & 97.1 & 91.8 & 92.9 & 90.7 & 90.0 \\
\hline$>+2$ & 7.7 & 15.4 & 1.4 & 2.9 & 4.7 & 4.7 & 5.0 & 8.5 \\
\hline \multicolumn{9}{|l|}{ Height-for-age } \\
\hline$<-2$ & 5.8 & 1.0 & $4.3^{a}$ & $4.3^{a}$ & $4.7^{c}$ & $5.9^{c}$ & 5.0 & 3.5 \\
\hline \pm 2 & 87.5 & 91.3 & 94.3 & 92.9 & 91.8 & 90.6 & 90.7 & 91.5 \\
\hline$>+2$ & 6.7 & 7.7 & 1.4 & 2.9 & 3.5 & 3.5 & 4.2 & 5.0 \\
\hline \multicolumn{9}{|c|}{ Weight-for-height } \\
\hline$<-2$ & 3.8 & 0.0 & $0.0^{b}$ & $0.0^{b}$ & 1.2 & 0.0 & 1.9 & 0.0 \\
\hline \pm 2 & 89.4 & 87.5 & 100.0 & 95.7 & 92.9 & 92.9 & 93.4 & 91.5 \\
\hline \multirow[t]{2}{*}{$>+2$} & 6.7 & 12.5 & 0.0 & 4.3 & 5.9 & 7.1 & 4.6 & 8.5 \\
\hline & \multicolumn{8}{|c|}{ Girls } \\
\hline No. examined & 138 & & 60 & & 106 & & 304 & \\
\hline \multicolumn{9}{|l|}{ Weight-for-age } \\
\hline$<-2$ & 5.8 & 0.7 & 3.3 & 0.0 & 3.8 & 0.0 & 4.6 & 0.3 \\
\hline \pm 2 & 87.7 & 87.7 & 90.0 & 86.7 & 95.3 & 91.5 & 90.8 & 88.8 \\
\hline$>+2$ & 6.5 & 11.6 & 6.7 & 13.3 & 0.9 & 8.5 & 4.6 & 10.9 \\
\hline \multicolumn{9}{|l|}{ Height-for-age } \\
\hline$<-2$ & 5.1 & 2.2 & $8.3^{d}$ & $5.0^{d}$ & 1.9 & 0.9 & 4.6 & 2.3 \\
\hline \pm 2 & 89.1 & 89.1 & 83.3 & 90.0 & 96.2 & 97.2 & 90.5 & 92.1 \\
\hline$>+2$ & 5.8 & 8.7 & 8.3 & 5.0 & 1.9 & 1.9 & 4.9 & 5.6 \\
\hline \multicolumn{9}{|c|}{ Weight-for-height } \\
\hline$<-2$ & 1.4 & 0.0 & 3.3 & 1.7 & 2.8 & 0.0 & 2.3 & 0.3 \\
\hline \pm 2 & 90.6 & 87.0 & 86.7 & 86.7 & 93.4 & 90.6 & 90.8 & 88.2 \\
\hline$>+2$ & 8.0 & 13.0 & 10.0 & 11.7 & 3.8 & 9.4 & 6.9 & 11.5 \\
\hline
\end{tabular}

Categories with common superscripts had mean Z-scores that were not significantly different (before vs after paired t-test).

er's work and mother's education. This indicates that these factors modified the response to the intervention programme. As regards sex, the interaction was significant only with HAZ scores where the improvement was more pronounced among girls $(-0.05$ to 0.20$)$ than boys $(-0.05$ to 0.01$)$. The effect of nursery was observed with the 3 nutrition indices; the increase was more pronounced in Anfushy nursery than both Smouha and Boulkly. Mother's work interacted with the intervention for HAZ scores with more improvement among children of non-working mothers (from -0.07 to 0.22$)$ than working mothers $(-0.03$ to 0.06$)$. With mother's education

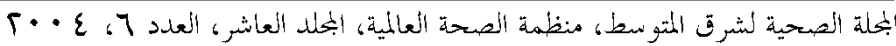




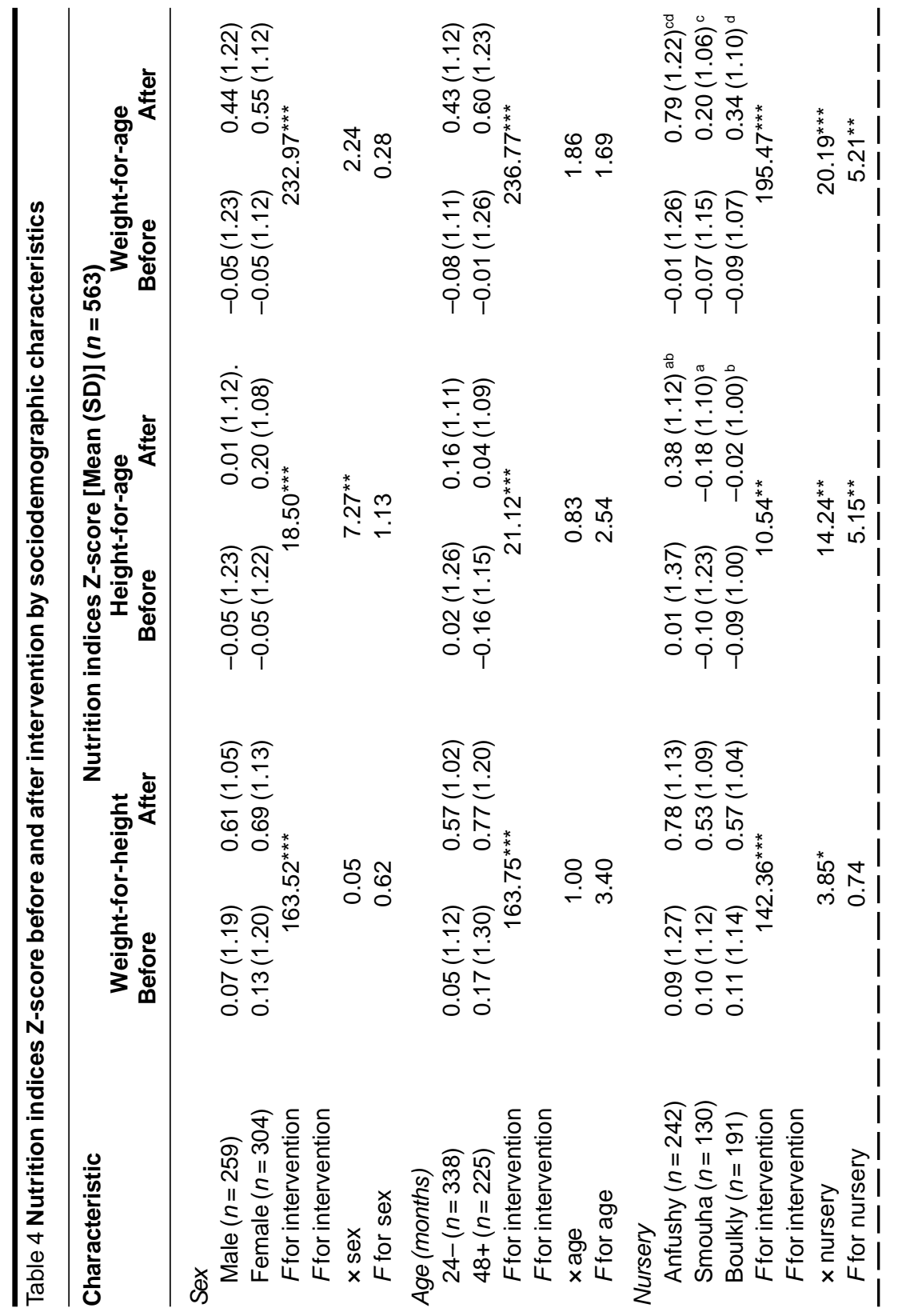

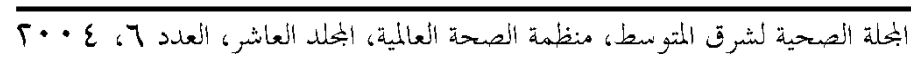




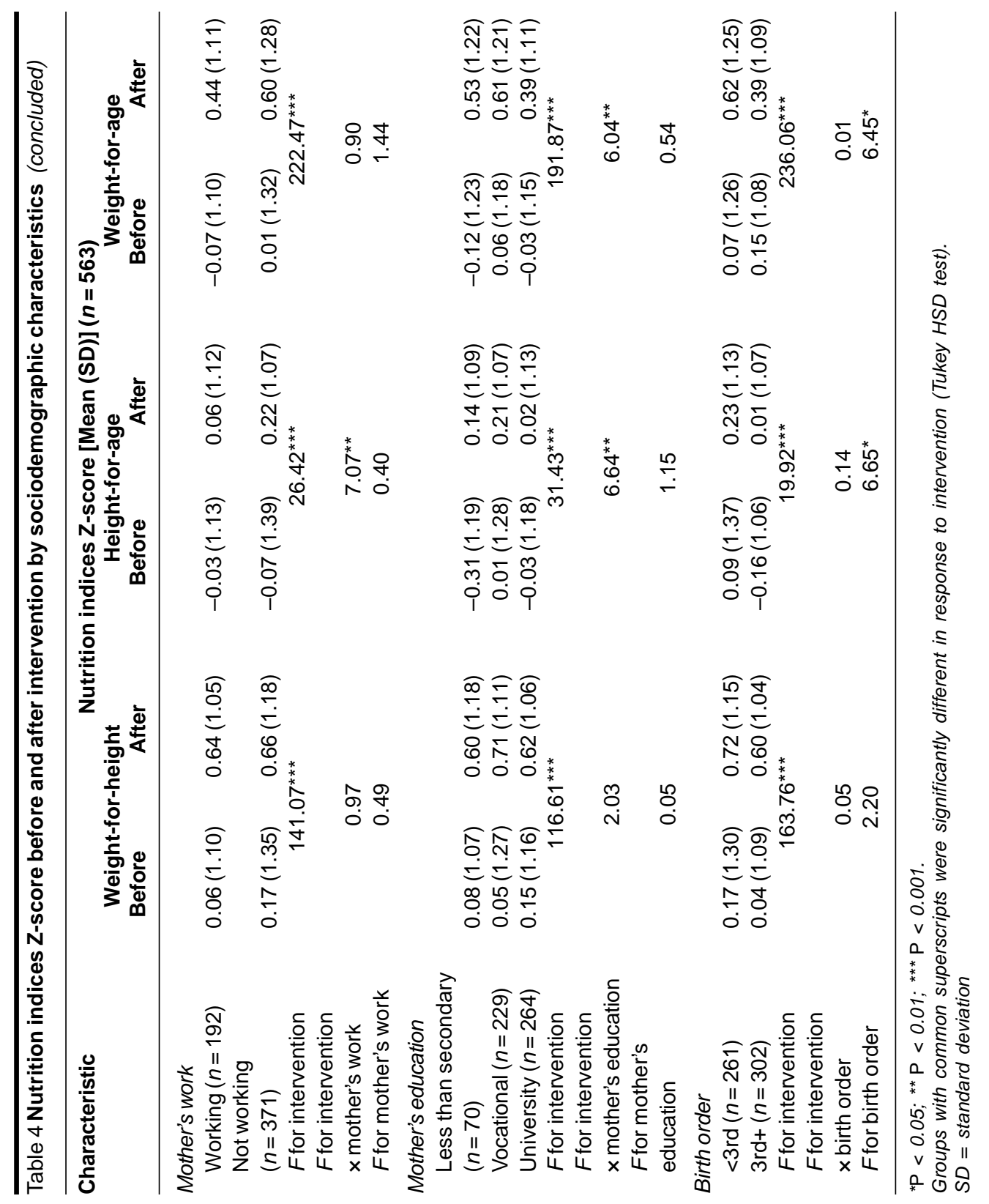

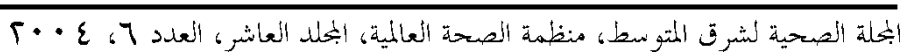


the interaction effect was significant with both HAZ and weight-for-age Z (WAZ) scores. Children of university educated mothers showed minimal increase in HAZ score $(-0.03$ to 0.02$)$ and WAZ score $(-0.03$ to 0.39$)$ compared to children of illiterate mothers $(-0.31$ to 0.14 and -0.12 to 0.53 respectively). The comparative figures for those of vocationally educated mothers were 0.01 to 0.21 and 0.06 to 0.61 respectively.

Another significant between-group effect was observed by nursery and by birth order (in HAZ and WAZ scores). Anfushy nursery had higher Z-scores for children than both Smouha and Boulkly whether at baseline or 1 year after intervention and lower ranked children in birth order (below third) had higher $\mathrm{Z}$ scores than the higher ranked children (third or higher) both at baseline and at final assessment.

The impact of the nutrition programme on the blood haemoglobin level is shown in Figure 1. There was a shift in the distribu- tion of children from the low haemoglobin levels (the peak of the curve below 10 $\mathrm{g} / \mathrm{dL}$ ) to a peak curve after intervention at $11 \mathrm{~g} / \mathrm{dL}$ or higher.

In Table 5 the overall prevalence of anaemia among children examined was $47.3 \%$ which decreased significantly after intervention to $14.2 \%$. Boys and girls were similar at baseline in the prevalence of anaemia (47.8\% and $46.8 \%$ respectively) and the drop was significant and to the same extent in both groups $(15.9 \%$ and $12.7 \%$ respectively). For all the other socioeconomic characteristics (age, nursery, mother's work, mother's education and birth order) the prevalence of anaemia decreased significantly after the intervention $(P<0.05)$.

Table 6 presents the mean haemoglobin levels before and after intervention by sociodemographic factor. The within subject intervention effect was significant for all groups $(P<0.001)$ and no significant interaction effect was found for any variable.

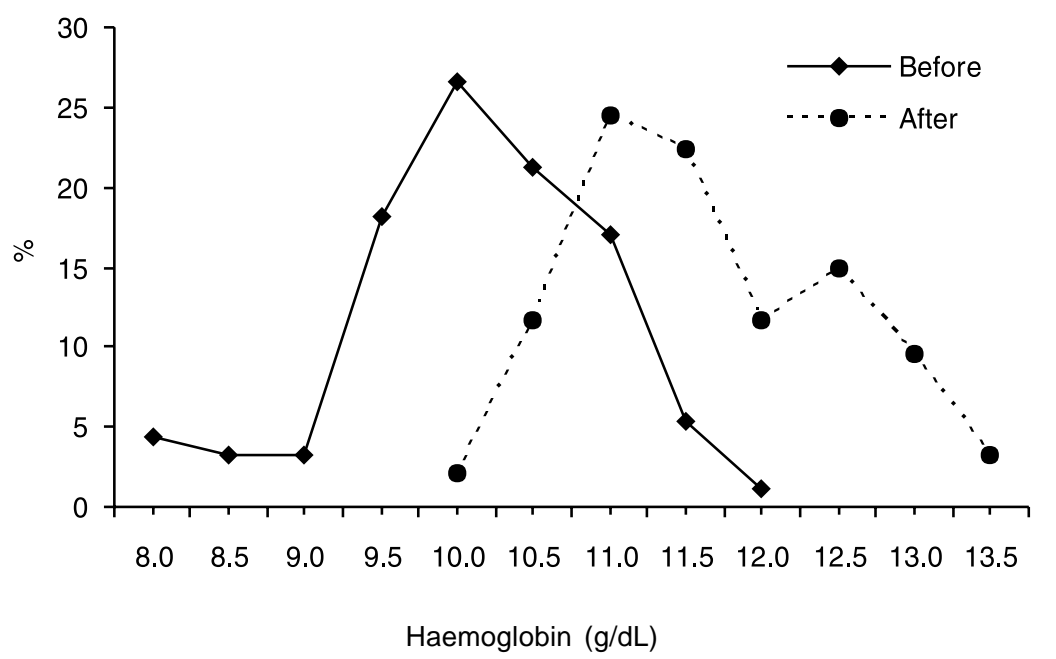

Figure 1 Haemoglobin level before and 1 year after the intervention

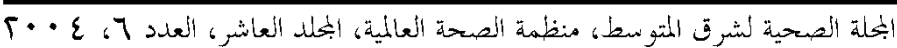


The only between-subjects effect was encountered with nursery where children of Anfushy nursery had a significantly higher haemoglobin level both at baseline and at final assessment than those of Smouha nursery.

In Figure 2, the mean lead and cadmium before and 1 year after the programme are presented. Both blood lead and cadmium were low at baseline assessment $(1.55 \mu \mathrm{g} / \mathrm{L}$ and $0.24 \mu \mathrm{g} / \mathrm{dL}$ respectively) and decreased significantly after intervention to 0.80 $\mu \mathrm{g} / \mathrm{dL}$ and $0.09 \mu \mathrm{g} / \mathrm{L}$ respectively.

\section{Discussion}

Good nutrition is essential for proper growth during childhood. To grow up healthy, with vitality and energy, children need adequate nutrition. Many nutrition intervention programmes have been tried to improve the nutritional status of children $[6,7,19]$. However, no single intervention or mix of interventions should ever be prescribed in isolation from a participatory process of problem assessment, causal and capacity analysis and programme design.

\begin{tabular}{|c|c|c|c|}
\hline \multirow[t]{2}{*}{ Characteristic } & \multicolumn{2}{|c|}{ Percentage anaemic } & \multirow[t]{2}{*}{ McNemar exact $P^{a}$} \\
\hline & Before & After & \\
\hline Overall $(n=148)$ & 47.3 & 14.2 & 0.000 \\
\hline \multicolumn{4}{|l|}{ Sex } \\
\hline Male $(n=69)$ & 47.8 & 15.9 & 0.000 \\
\hline Female $(n=79)$ & 46.8 & 12.7 & 0.000 \\
\hline \multicolumn{4}{|l|}{ Age (months) } \\
\hline $24-(n=89)$ & 39.0 & 13.6 & 0.000 \\
\hline $48+(n=59)$ & 52.8 & 14.6 & 0.000 \\
\hline \multicolumn{4}{|l|}{ Nursery } \\
\hline Anfushy $(n=92)$ & 65.0 & 35.0 & 0.031 \\
\hline Smouha $(n=20)$ & 55.6 & 11.1 & 0.000 \\
\hline Boulkly $(n=36)$ & 40.2 & 10.9 & 0.000 \\
\hline \multicolumn{4}{|l|}{ Mother's work } \\
\hline Working $(n=75)$ & 46.6 & 17.8 & 0.000 \\
\hline Not working $(n=73)$ & 48.0 & 10.7 & 0.000 \\
\hline \multicolumn{4}{|l|}{ Mother's education } \\
\hline $\begin{array}{l}\text { Less than secondary } \\
(n=25)\end{array}$ & 40.0 & 12.0 & 0.039 \\
\hline Vocational $(n=67)$ & 49.3 & 13.4 & 0.000 \\
\hline University $(n=56)$ & 48.2 & 16.1 & 0.000 \\
\hline \multicolumn{4}{|l|}{ Birth order } \\
\hline$<3 r d(n=81)$ & 48.1 & 17.3 & 0.000 \\
\hline $3 r d+(n=67)$ & 46.3 & 10.4 & 0.000 \\
\hline
\end{tabular}

${ }^{a}$ Binomial distribution used. 


\begin{tabular}{|c|c|c|c|c|c|c|c|}
\hline \multicolumn{5}{|c|}{ Eastern Mediterranean Health Journal, Vol. 10, No. 6, 2004} & \multirow{2}{*}{\multicolumn{3}{|c|}{ n by sociodemographic characteristics }} \\
\hline \multicolumn{5}{|c|}{ Table 6 Haemoglobin level before and after intervention by sociodemographic characteristics } & & & \\
\hline \multirow[t]{2}{*}{ Characteristic } & \multicolumn{4}{|c|}{ Haemoglobin $(g / d L)$} & \multirow{2}{*}{$\begin{array}{c}F \text { for } \\
\text { intervention }\end{array}$} & \multirow{2}{*}{$\begin{array}{l}\text { F for } \\
\text { intervention } \\
\times \text { factor }\end{array}$} & \multirow{2}{*}{$\begin{array}{c}\text { F for } \\
\text { between } \\
\text { group effect }\end{array}$} \\
\hline & $\begin{array}{c}\text { Be } \\
\text { Mean }\end{array}$ & ore & $\begin{array}{r}\boldsymbol{A}^{\prime} \\
\text { Mean }\end{array}$ & $S D$ & & & \\
\hline Sex & & & & & $97.73^{\star \star *}$ & 0.53 & 0.78 \\
\hline Male $(n=69)$ & 10.96 & 0.88 & 11.52 & 0.78 & & & \\
\hline Female $(n=79)$ & 11.03 & 0.86 & 11.67 & 0.86 & & & \\
\hline Age (months) & & & & & $95.09^{* * *}$ & 0.01 & 1.55 \\
\hline $24-(n=89)$ & 11.09 & 0.90 & 11.70 & 0.82 & & & \\
\hline $48+(n=59)$ & 10.93 & 0.84 & 11.53 & 0.82 & & & \\
\hline Nursery & & & & & $69.59^{* * *}$ & 0.04 & $3.07^{*}$ \\
\hline Anfushy $(n=92)$ & 11.10 & 0.91 & 11.70 & 0.77 & & & \\
\hline Smouha $(n=20)$ & 10.63 & 1.08 & 11.28 & 0.97 & & & \\
\hline Boulkly $(n=36)$ & 10.94 & 0.52 & 11.54 & 0.84 & & & \\
\hline Mother's work & & & & & $98.79^{\star \star *}$ & 0.01 & 0.38 \\
\hline Working $(n=75)$ & 11.03 & 0.76 & 11.64 & 0.83 & & & \\
\hline Not working $(n=73)$ & 10.95 & 0.97 & 11.56 & 0.81 & & & \\
\hline $\begin{array}{l}\text { Mother's education } \\
\text { Less than }\end{array}$ & & & & & $91.91^{* * *}$ & 0.73 & 0.69 \\
\hline secondary $(n=25)$ & 10.82 & 1.11 & 11.59 & 0.80 & & & \\
\hline Vocational $(n=67)$ & 11.09 & 0.79 & 11.66 & 0.86 & & & \\
\hline University $(n=56)$ & 10.96 & 0.84 & 11.53 & 0.79 & & & \\
\hline Birth order & & & & & $98.75^{\star \star *}$ & 0.15 & 0.01 \\
\hline$<3 \mathrm{rd}(n=81)$ & 11.00 & 0.80 & 11.58 & 0.86 & & & \\
\hline $3 r d+(n=67)$ & 10.99 & 0.95 & 11.62 & 0.78 & & & \\
\hline
\end{tabular}

${ }^{*} \mathrm{P}<0.05 ;{ }^{* * * P}<0.001$.

There was a significant difference in response to intervention between Smouha and Anfushy (Tukey HSD test).

$S D=$ standard deviation

Participatory problem-solving approaches will reveal the main causes of undernutrition and the type and amount of resources available to combat it [20].

The present study is a demonstration of a participatory process of problem-solving including problem assessment, causal and capacity analysis and programme design. The baseline problem assessment analysis revealed that, with the exception of protein, vitamins $A$ and $B_{2}$ all nutrients were deficient compared with the RDAs, about $50 \%$ of children were anaemic, and underweight, stunting and wasting among boys and girls were about $4.2 \%, 5.0 \%$ and $1.9 \%$ respectively. Furthermore, were mean blood lead and cadmium were $1.55 \mathrm{mg} / \mathrm{dL}$ and $0.24 \mathrm{mg} / \mathrm{dL}$ respectively. An analysis of dietary intake of preschool Indian children belonging to poor income groups indicated a similar deficiency of nutrients [8]

Risk-factor analysis revealed consistent deficiency in nutrients by sex, age, mother's work, and mother's education. This consistency of results indicates that the problem is universal and all study groups needed intervention.

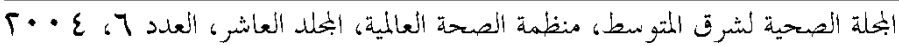




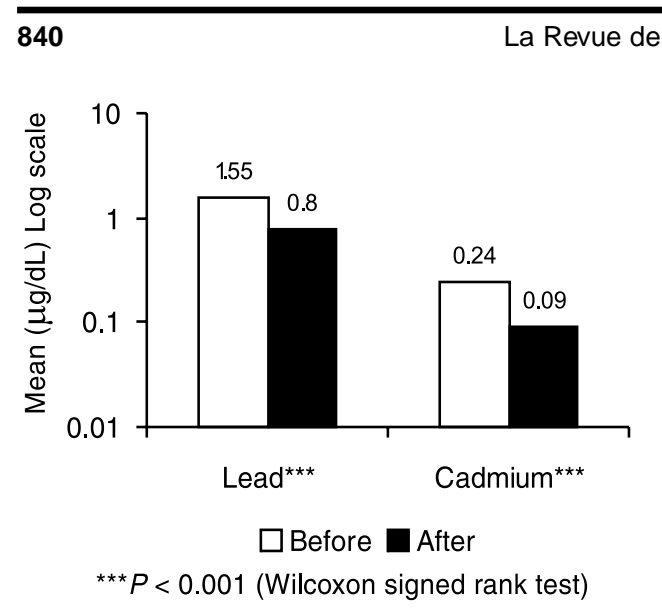

Figure 2 Mean lead and cadmium before and after intervention

Similar programmes implemented in other countries have shown success over the same period of time [22], a relatively longer period of time [22] or did not achieve improvement [23]. The post-test situation of the current programme revealed considerable improvement in the nutritional status of children whether in anthropometric measurements or in haemoglobin level. One year after the programme, the proportion with a haemoglobin level of $12+\mathrm{g} / \mathrm{dL}$ increased from $10.9 \%$ to $44.5 \%$ among boys and from $15.5 \%$ to $44.5 \%$ among girls and the improvement was consistent for all study groups (Tables 4-6). A similar project in the Islamic Republic of Iran, which did not include intervention feeding, reported a drop in wasting from $6.5 \%$ to $1.8 \%$ [24]. The comparable figures in the present study were $1.9 \%$ to zero among boys and $2.3 \%$ to $0.3 \%$ among girls.

The significant interaction between the area and degree of improvement after the programme in the 3 anthropometric indicators reflects the higher level of cooperation among mothers of the lower income locali- ty (Anfushy) relative to the higher income localities (Smouha and Boulkly). Lower income mothers were pleased to offer food supplements to their children. The same can explain the interaction of HAZ and WAZ indices with mothers' work and education which were correlated by area.

Mahaffey reported that the burden of iron deficiency anaemia is amplified for children who have lead toxicity, since at the same blood lead levels the adverse effects are increased if iron deficiency is present [25]. Cadmium is another toxic metal with a long history of detrimental effects. It accumulates in humans throughout their lives because of its very long half-life [26]. Cadmium has an adverse effect on brain metabolism [27]. Also, it has been demonstrated to aggravate anaemia by suppressing erythropoietin gene expression in anaemic patients [28]. So the design of the present intervention considered the elimination or decline of blood lead and cadmium currently and in the future through increasing mother's awareness of the factors causing lead and cadmium toxicity and presentation of healthy food which helps the elimination of blood lead. Evaluation of the programme revealed that both blood lead and cadmium were lower after the programme.

Some researchers have documented a significant relationship between nutrition knowledge and nutrition behaviour [29,30]. Comparison of the mean knowledge score of mothers before and after the intervention indicated the beneficial effect of the educational sessions. This concurs with the results of a community-based study in Delhi including a nutrition education of 4 months where mothers showed significantly higher nutrition knowledge and the dietary iron intake of children was significantly higher than their control group counterparts [30] 
Past experience has suggested that around US\$ 5 to 15 per participant per year seems to be associated with effective programmes, at least for those that do not include provision of additional food which approximately doubles the cost [20]. In many cases, well conceived programmes may be ineffective simply because their coverage is too low to have a broad impact on the problem, or because they do not reach those most in need. In other cases, the principles may be correct but the level of resources committed may be unrealistically low so nothing much can really be achieved [19].

Analysis of the cost of the present programme per subject indicated US\$20.5 per child per year was within the range of effective nutrition intervention programmes; this includes provision of additional food.

A finding in the present study that was not intended but expected is the shift of the nutrition status toward overweight. Mothers would not accept a loss in the body weight of their children even if they were overweight at the start of a study even though it aimed at improving the nutritional status of children. However, it is expected that the knowledge mothers acquired on healthy food will eliminate the possibility of obesity in the study group in the long run.

This programme has been sustainable by increasing the nursery fees by LE 5 per month which, added to the original feeding fund of LE 3500 per month, allows for this programme to continue.

\section{Conclusions}

Nutrition intervention can be provided to preschool children in day care centres. Short interventions appear to be practical strategies for improving the nutritional status of children.

\section{Acknowledgement}

Financial support for this study was received from the Social Fund for Development (SFD).

\section{References}

1. El-Zanaty F, Way AA. Egypt Demographic and Health Survey 2000. Cairo, Ministry of Health and Population, National Population Council; Calverton, Maryland, ORC Macro, 2001.

2. El Abd AM. Assessment of the present food consumption patterns and nutritional status of preschool children in light of the emerging nutrition transition [MPH thesis]. Alexandria, High Institute of Public Health, University of Alexandria, 2000.

3. Ghoneim EH, Hassan MHA. Prevalence of iron deficiency anemia among preschool children in Alexandria. Bulletin of the High Institute of Public Health, 2000, 30:579-90.

4. Basaleem HO, El-Sahn FAF, Hassan MHA. Nutritional status of children in squatter and urban areas in Alexandria, Egypt. Yemen journal of medical and health research, 2003, 2:29-47.

5. El-Masry AM. Parasitic infections and malnutrition in rural preschool children in a Northern Nile Delta area, Egypt. Bulletin of the High Institute of Public Health, 2003, 33:221-38.

6. Ayob A. The implementation of nutrition education in preschools in Malaysia. Paper presented at the 2000 conference of

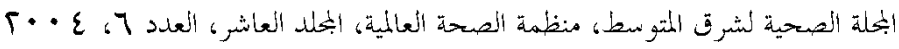


the Australian Association for Research in Education Australian Association for Research in Education, Sydney, December, 2000. Available at: http://www. aare.edu.au/00pap/ayo00511.htm (accessed $31 / 3 / 05$ )

7. Sari M et al. Effect of iron-fortified candies on the iron status of children aged 4-6 y in East Jakarta, Indonesia. American journal of clinical nutrition, 2001, 73:1034-9.

8. Rao BS. Approaches to intervention among children and adolescents. Nutrition reviews, 2002, 60:S118-25

9. The dietary guidelines for Americans, 1995. Available at: http://www. health. gov/dietaryguidelines/dga95/ default.htm (accessed 31/3/05).

10. Devaney BL, Gordon AR, Burghardt JA. Dietary intakes of students. American journal of clinical nutrition, 1995, 61(1 suppl.): S205-12.

11. Guidelines for School Health Programs to Promote Lifelong Healthy Eating. Morbidity and mortality weekly report, 1996, (RR-9):1-41.

12. Federation of American Societies for Experimental Biology, Life Sciences Research Office. Third Report on Nutrition Monitoring in the United States, Volume 1. Washington DC, US Government Printing Office, 1995.

13. Food Composition Tables of Nutrition Institute of Egypt, 1993. Available on request from the Nutrition Institute of Egypt.

14. Mitchell MK. Nutrition across the life span. Philadelphia, WB Saunders Company, 1997.

15. Official methods of analysis of AOAC international, 16th ed. Arlington, Virginia, Association of Official Analysis Chemists, 1994.

16. Guidelines for the control of iron deficiency anaemia in countries of the East- ern Mediterranean, Middle East and North Africa. Based on a Joint WHO/ UNICEF Consultation on Strategies for the Control of Iron Defieincy Anemia. Alexandria, World Health Organization Regional Office for the Eastern Mediterranean, 1996:7-51.

17. Norman GR, Streiner DL. Biostatistics, the bare essentials, 2nd ed. Hamilton, BC Decker Inc., 2000.

18. Norusis MJ. Repeated measures ANOVA. Chicago, SPSS Inc., Professional Statistics Release 10.0.5, 1999.

19. Schroeder DG et al. An integrated child nutrition intervention improved growth of younger, more malnourished children in northern Viet Nam. Food and nutrition bulletin, 2002, 23:53-61.

20. UNICEF. Strategy for improved nutrition of children and women in developing countries. New York, United Nations Children's Fund, 1990.

21. Pachon $\mathrm{H}$ et al. Effect of an integrated child nutrition intervention on the complementary food intake of young children in rural north Viet Nam. Food and nutrition bulletin, 2002, 23:62-9.

22. He Y et al. [Effect of nutrition on the health improvement of preschool children in rural areas.] Wei sheng yan jiu, 1999, 28(3):172-5 [in Chinese].

23. Khamhoung $\mathrm{K}$ et al. Nutritional status of preschool children and women in selected villages in the Suvannakhet Province, Lao PDR - an intervention trial. Southeast Asian journal of tropical medicine and public health, 2000, 31(suppl. 2):63-74.

24. Malekafzali $\mathrm{Hn}$ et al. Community-based nutritional intervention for reducing malnutrition among children under 5 years of age in the Islamic Republic of Iran. Eastern Mediterranean health journal, 2000, 6:238-45.

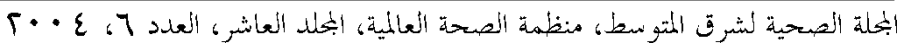


25. Mahaffey KR. Nutrition and lead: strategies for public health. Paper presented at the Symposium on Preventing Child Exposures to Environmental Hazards: Research and Policy Issues, 18-19 March 1994, Washington DC.

26. Savolainen H. Cadmium-associated renal disease. Renal failure, 1995, 17: 483-7.

27. Dreosti JE, Smith RM, eds. Neurobiology of the trace elements, Vol. 1. Trace element neurobiology and deficiencies. Clifton, New Jersey, Humana Press, 1983.

28. Chun $Y$ et al. Cadmium blocks hypoxiainducible factor (HIF)-1-mediated re- sponse to hypoxia by stimulating the proteasome-dependent degradation of HIF-1a. European journal of biochemistry, 2000, 267:4198-204.

29. Kanani S, Agarwal V. Reducing anemia and improving growth in early adolescence: Nutrition education alone can make a difference. Paper presented at the 16th International Congress of Nutrition, Montreal, Canada, 27 July-1 August, 1997.

30. Kapur D, Sharma S, Agarwal KN. Effectiveness of nutrition education, iron supplementation or both on iron status in children. Indian pediatrics, 2003, 40: 1131-44.

\section{Mote from the Editor}

We would like to inform our readers that the next Special Issue of the EMHJ (Volume 11, 2005) will be on Maternal and Child Health to reflect the theme for World Health Day 2005.

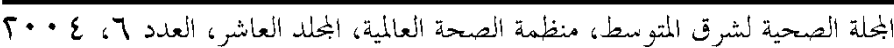

